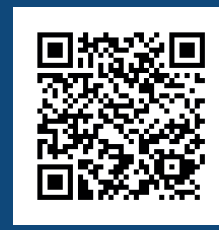

Keywords:

Copaifera spp

Diameter at breast height

Mean annual increment

Sustainability

Historic:

Received 26/02/2018

Accepted 03/07/2018

Correspondence: guilhermeroquette@yahoo.com.br

José Guilherme Roquette ${ }^{\mathrm{a}, 2+}$, Ronaldo Drescher ${ }^{2 \mathrm{a}}$, Gilvano Ebling Brondani ${ }^{3 \mathrm{a}}$, Edila Cristina Souza ${ }^{2 b}$, Rubens Marques Rondon Neto ${ }^{4 a}$, Alexandre Ebert ${ }^{5 a}$, Leandro Ribeiro Teixeira $^{2 c}$, André Pereira Dias ${ }^{5 b}$, Fernando Henrique Gava ${ }^{2 d}$

\title{
AGE AND GROWTH AFFECT OLEORESIN YIELD FROM COPAIBA TREES IN THE CERRADO-AMAZONIA ECOTONE
}

ROQUETTE, J. G.; DRESCHER, R.; BRONDANI, G. E.; RONDON NETO, R. M; EBERT, A.; TEIXEIRA, L. R.; DIAS, A. P.; GAVA, F. H. Age and growth affect oleoresin yield from copaiba trees in the cerrado-amazonia ecotone. CERNE, v. 24, n. 2, p. 106-113, 2018.

\section{HIGHLIGHTS}

Oleoresin production of Copaifera spp. under natural environment is dependent of the age and growth.

The methodology can be applied for the individual selection in natural environment.

Oleoresin production is variable in natural environment.

\section{ABSTRACT}

Copaiba trees, of the genus Copaifera (Fabaceae), produce an oleoresin that has pharmacological applications. The yield from the trees is very variable, and factors affecting production are still unknown. We evaluated the yield of oleoresin from Copaifera spp. in the CerradoAmazonia ecotone, as well as its relationship with the growth and age of trees. We sampled 30 Copaifera trees by extracting oleoresin for $24 \mathrm{~h}$ with a metal borer. Increment cores were collected from 15 trees to determine their age by counting growth rings and to calculate the mean annual increment of the diameter at breast height. The cylinders were sanded and the number of growth rings was counting with a magnifying glass (I0x). The ages of trees from which increment cores were not collected were estimated by simple regression analysis. The proportions of productive and non-productive trees were recorded. The best adjusted model for age estimation showed $\mathrm{R}^{2}$ adjust. $=0.616$ and Syx $\%=4.42$. The average productivity of oleoresin was $0.124 \mathrm{~L}$ per day, and $30 \%$ of the trees were productive. The proportion of productive trees increased with increasing diameter at breast height and age, but after a point, increasing diameter was associated with reduced productivity. The mean annual increment had an inverse relationship with diameter for the productivity of oleoresin. The results suggest that other factors could be triggering and controling the oleoresin production and not only the age.

' Procuradoria Geral de Justiça de Mato Grosso, Cuiabá, Mato Grosso, Brazil, ORCID: 0000-0003-0645-9173a

${ }^{2}$ Federal University of Mato Grosso, Cuiabá, Mato Grosso, Brazil, ORCID: 0000-000 I-9549-650 Ia, 0000-000 I5528-8804 , 0000-0003-3634-5978c, 0000-0002-0488-6342 d

${ }^{3}$ Federal University of Lavras, Lavras, Minas Gerais, Brazil, ORCID: 0000-000 I-8640-57I 9

${ }^{4}$ State University of Mato Grosso - Alta Floresta, Mato Grosso, Brazil, ORCID: 0000-0003- 1779-4970a 0003-2585-0602 


\section{INTRODUCTION}

Copaiba trees, 46 species which belong to the genus Copaifera (Fabaceae), are found in the tropical regions of South and Central Americas, West Africa and maybe Asia (Martins-da-Silva, 2006). According to Martins-da-Silva et al. (2008), there are nine distinct species in the Amazon region of Brazil, including some species that have a range of physical characteristics, which makes correct identification difficult.

Copaiba trees produce an oleoresin with multiple applications, which is also used as a source of bioactive molecules in pharmacological applications (Veiga Junior and Pinto, 2002). It is a byproduct of the excretion or detoxification of the tree that is used as defense against animals, fungi, and bacteria when exuded by slits in the decaying wood (Alencar, 1982; Plowden, 2003). Oleoresin has been used to treat a number of airway diseases and respiratory, dermal, and mucosal infections in humans, and it has aphrodisiac, anti-tetanus, anti-rheumatic, antiheadache, and anti-venom properties (Veiga Junior and Pinto, 2002; Pieri et al., 2009). It is used as a raw material in creams, shampoos, and soaps in the cosmetic industry and in varnishes, lacquers, paints, perfume fixatives, and papermaking (Ferreira and Braz, 200I).

Factors that hamper its commercial exploitation are the high variation in the yield of oleoresin by copaiba trees and the limited proportion of productive trees in a population. Although some studies have tried to explain the factors associated with copaiba production, uncertainties still remain (Alencar, 1982; Baima et al., 1999; Ferreira and Braz, 200I; Rigamonte-Azevedo et al., 2004; Oliveira et al., 2006; Rigamonte-Azevedo et el., 2006; Medeiros and Vieira, 2008; Barbosa et al., 2009; Newton et al., 20II; Martins et al., 20I3; Souza and Higuchi, 20I4). Tree growth is related to oleoresin yield, and physiological conditions are expected to influence its production (Plowden, 2003).

Dendrochronology is a powerful science to study the dynamics of tree growth (Vlam et al., 2014). Based on the age distribution and the characteristics of the tree rings, inferences can be made to support sustainable forest management (López et al., 20 I3; Vlam et al., 2014).

The region between Amazonia and the Cerrado in Brazil is experiencing high rates of forest exploitation and deforestation for economics activities. However, oleoresin is a potential alternative product in the region that could generate an economic return without causing deforestation. In this sense, the aim of the present study was to evaluate the yield of oleoresin from Copaifera spp. in a primary forest in the Amazonia-Cerrado ecotone and to determine the relationship between oleoresin yield and tree age and growth, in order to evaluate whether copaiba could be sustainably harvested in the region.

\section{MATERIAL AND METHODS}

\section{Study area}

The study was performed in a 213-ha area of a primary forest located in the Legal Reserve Area of a private property in the Municipality of Vera, in the central north region of the State of Mato Grosso, Brazil (Figure I). An inventory of the forest was conducted in 2011 for logging purposes, although the area contains species that have potential as non-timber resources as well. The geographical coordinates of the area are $12^{\circ} 42^{\prime} 54^{\prime \prime} S$ and $55^{\circ} 19^{\prime} 53^{\prime \prime} \mathrm{W}$ (Datum WGS84, 2IS), and the altitude is around $330 \mathrm{~m}$ above sea level.

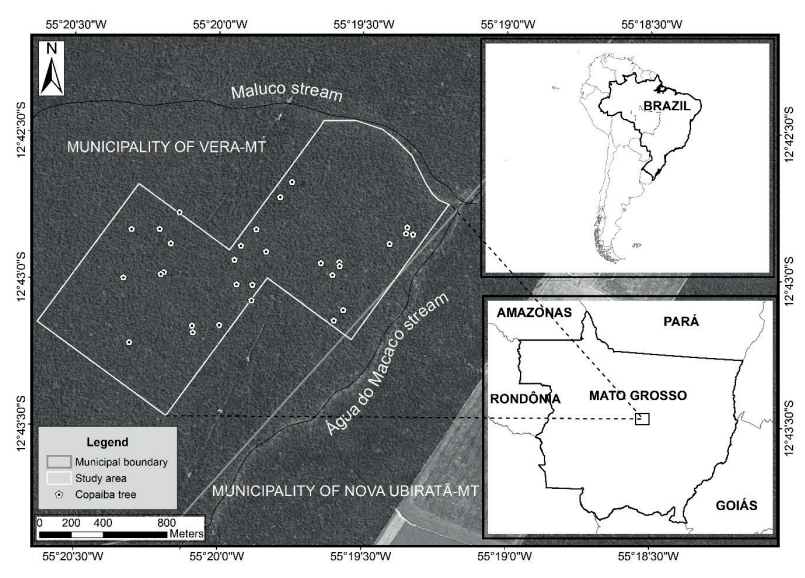

FIGURE I Localization of the study area in the CerradoAmazonia ecotone in the central north region of Mato Grosso State, Brazil.

The region is located in the watershed of the Amazon River. The vegetation is classified as lowland semi-deciduous seasonal forest with an emergent canopy and characterized by species from the Amazon, and overlaps with both the tropical rainforest and the Cerrado (Cerrado-Amazonia ecotone) (Ibge, 2012). The typical climate during most of the year is humid, with only three dry months, a maximum temperature above $18^{\circ} \mathrm{C}$ across the year, and an annual rainfall of 1850 to $2050 \mathrm{~mm}$ (Köppen classification Aw) (Inmet, 1992).

The soil is classified as dystrophic Yellow Red Latosol plinthic and has a typical medium texture, with a low natural fertility and contains excess aluminum. The relief, formed by the accumulation of sediments over the years, is known as Parecis Plateau (Ibge, 2009a; 2009b; 2009c).

\section{Data collection}

The forest inventory of the study area for forest exploitation (census of the trees with $\geq 0.25$ m diameter at breast height $(\mathrm{DBH})$; unpublished data) identified 72 Copaifera trees (2.95 trees ha-1), of which 30 were 
selected for the present study based on their $\mathrm{DBH}$. These trees had a DBH greater than $0.30 \mathrm{~m}$ and were selected because trees with lower DBH do not produce oleoresin (Plowden, 2003). The trees were also selected to create a sample that was distributed across DBH values and ages.

There were seven samples in the $0.30-0.42 \mathrm{~m}$ DBH class, six for $0.42-0.54 \mathrm{~m}, \mathrm{II}$ for $0.54-0.66 \mathrm{~m}$, and six for $0.66-0.78 \mathrm{~m}$. Before oleoresin collection, the circumference at breast height $(\mathrm{CBH})$ of the trees was measured again with a tape measure. The values were converted to $\mathrm{DBH}$ using the following formula:

$\mathrm{DBH}=\frac{\mathrm{CBH}}{\pi}$

The extraction of oleoresin from the Copaifera trees was performed during timber harvesting activities in the study area, from July through September 2012, the dry season in the region. For the extraction, a hole was bored at breast height using a I.9I- $\mathrm{cm}$ metal borer. The hole's location was below the main branch or on the side toward which the trunk was inclined.

After we had bored to the center of the trunk, often surpassing the pith, we inserted a plastic hose in the hole and connected it to a 5-L plastic barrel, affixing it with adhesive tape. Even in trees that did not produce oleoresin during the boring, the hose connected to the barrel was left inserted for $24 \mathrm{~h}$, following the methods of Rigamonte-Azevedo et al. (2006). After oleoresin collection, the hole was sealed to protect the tree against possible attacks from pathological organisms. The sealing was performed with branch wood near each tree; the wood was cut and debarked with a machete.

The oleoresin obtained was stored in barrels marked with the identity of the trees and subsequently transferred to a laboratory for volume measurement in test tubes with a milliliter scale. The trees were considered productive if the amount of oleoresin extracted leaked out of the barrel into the test tubes and non-productive if the quantity was not sufficient to flow out and the oleoresin remained in the inner surface of the pipe or barrel.

Individual age was estimated by counting the number of growth rings, which are marked by parenchyma cells in copaiba trees (Figure 2) (Mainieri and Chimelo, 1989). According to Pereira et al. (2018), there is a high correlation between growth rings in copaiba populations, whose series is strongly influenced by environmental factors. We sampled 17 trees for age determination; one wood increment core perpendicular to the hole for oleoresin extraction were removed after complete exudation using an increment borer. Two of the 17 trees were hollow and yours increment cores were discarded. The holes made by the increment borer were sealed in the same manner as the holes for oleoresin extraction. To allow better visualization of the anatomical structures, the samples were sanded using sandpaper with 100,150,220,320, and 400 grains of sand per $\mathrm{cm}^{2}$ and then the number of growth rings was counted, using a magnifying glass $(10 \times)$.

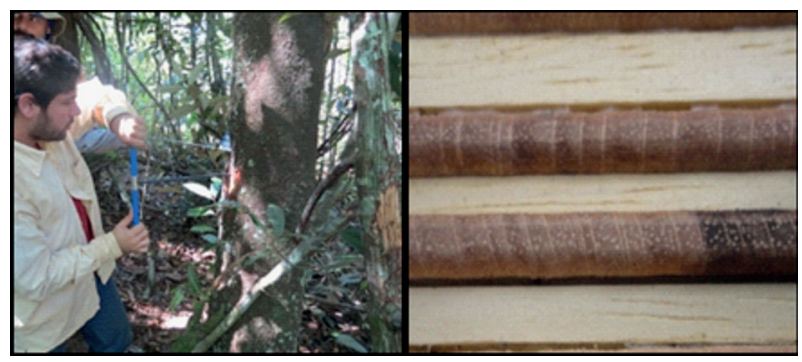

FIGURE 2 Copaifera spp. and habitat, and the Copaifera spp. growth rings in the Cerrado-Amazonia ecotone in the central north region of Mato Grosso State, Brazil.

Processing and data analysis

The age of the 15 trees from which no wood cylinder was collected was estimated using linear regression analysis. In regression analysis, samples with fewer than 30 observations are appropriate for analysis only by simple regression using a independent variable with strong correlation (Hair et al., 2009). For this analysis, the age (dependent variable) was estimated on the basis of its relationship with the $\mathrm{DBH}$ (independent variable).

Prior to fitting the model, we evaluated the variables to verify the statistical assumptions of normality (Shapiro-Wilk test, $\alpha=0.05$ ), linearity, and homoscedasticity (scatterplot analysis), eliminating the possibility that the relationship was misrepresented (Hair et al., 2009). To improve the correlation between age and $\mathrm{DBH}$, the variables were transformed before the models were adjusted.

Four equations were selected for the residual plot analysis to obtain the highest adjusted coefficient of determination $\left(R_{\text {adjust. }}^{2}\right.$ ), lowest standard error of estimate $\left(\mathrm{S}_{\mathrm{yx}} \%\right)$, and significance according to the $\mathrm{F}$ test, as well as the estimated coefficients according to the $t$-test (both at a level of $5 \%$ probability).

The mean annual increment (MAl) was calculated as the ratio of $\mathrm{DBH}$ to the individual's age. This variable was used to evaluate if the copaiba trees were in a senescence or growth phase under unfavorable conditions. After we obtained the data for age and MAl of $\mathrm{DBH}$, the proportion of productive trees in the different classes of the studied variables (DBH, age, and MAI) was 
verified. The oleoresin yield was used in the descriptive statistical analysis, in which we compared the region's yield (minimum, maximum, and average) and production (productive or non-productive) with those data for other Amazon regions.

\section{RESULTS}

The $\mathrm{DBH}$ and age variables both showed a normal distribution at the 0.05 significance level $(\mathrm{DBH}: \mathrm{W}=0.919$, $p$-value $=0.189$; age: $\mathrm{W}=0.964, p$-value $=0.760)$ and complied with the statistical assumptions for the simple regression analysis. The scatterplot revealed a low tendency to linearity and homoscedasticity (Figure 3). An atypical observation around 140 years was eliminated to improve the correlation between the variables, which changed the value of the Pearson coefficient of correlation from $0.67 \mathrm{I}$ to 0.761 . This shows how complex are the growth trajectories of the trees growing up in a such complex forest and the difficulties to estimate the age with the $\mathrm{DBH}$.

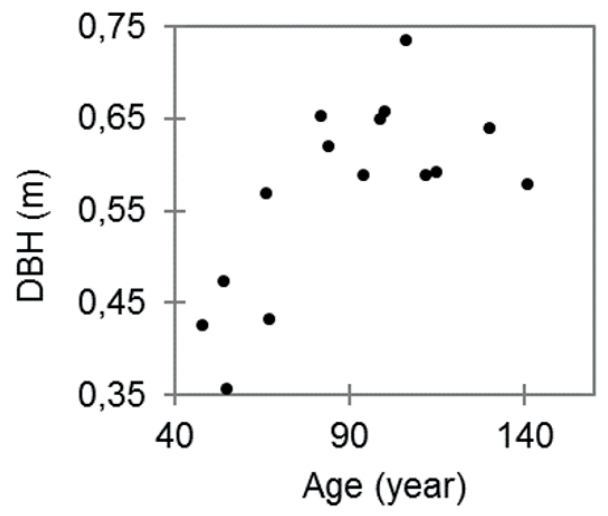

FIGURE 3 Scatterplot for diameter at breast height (DBH) and age of Copaifera trees in the Cerrado-Amazonia ecotone in the central north region of Mato Grosso State, Brazil.

Even after verifying that the $\mathrm{DBH}$ and age variables complied with the statistical assumptions, the adjustment of the equations showed better results after the inverse, square, root, and/or, mainly, logarithmic transformations of the variables. The best four adjusted equations were selected through the observation of residuals plot, and the results of the intercepts $(\beta 0)$ and regression coefficients $(\beta i)$, adjusted coefficients of determination $\left(R^{2}{ }_{\text {adjust. }}\right)$, standard errors of estimate $\left(\mathrm{S}_{\mathrm{yx}} \%\right)$, and $\mathrm{F}$ test were considered (Figure 4).

Models I.2, I.3, and I.4 showed similar statistical parameters. Model I.3 was selected to estimate the age and showed superior $\mathrm{R}_{\text {adjust. }}^{2}$ and less standard error of estimate than the other two models. The residuals plots were similar in all the models. Although model I.I showed the best $R_{\text {adjust. }}^{2}(0.656)$, it was discarded because of the high value of the standard error of estimate (19.33\%).
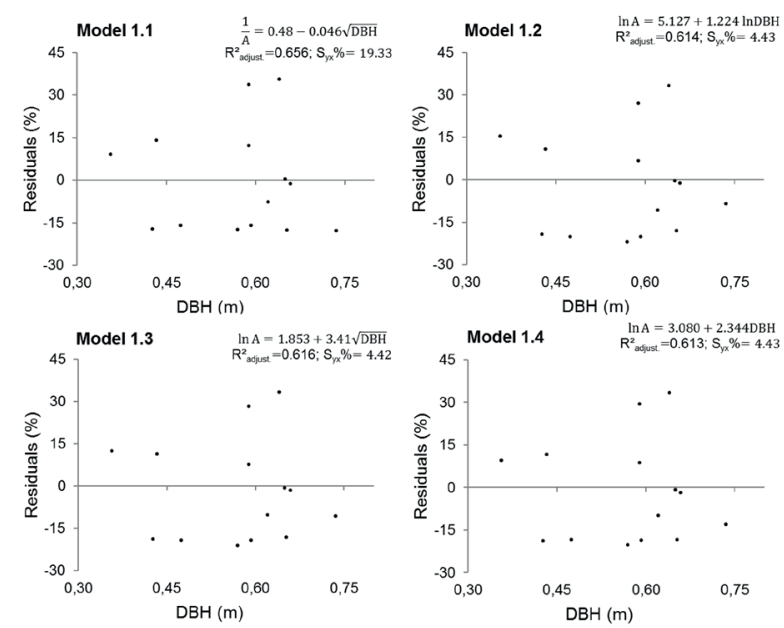

FIGURE 4 Scatterplot for diameter at breast height $(\mathrm{DBH})$ and age of Copaifera trees in the Cerrado-Amazonia ecotone in the central north region of Mato Grosso State, Brazil.

Among the 30 copaiba trees selected for oleoresin extraction, only 9 (30\%) were productive, including 5 that were hollow and were distributed among all the $\mathrm{DBH}$ classes. The average yield of copaiba oleoresin was 0.124 $\pm 0.079 \mathrm{~L}_{\text {tree }}^{-1} 24 \mathrm{~h}^{-1}$, with a maximum value of $2.352 \mathrm{~L}$ tree $^{-1} 24 \mathrm{~h}^{-1}$. There was a large variation $(\mathrm{CV}=349.9 \%)$ and distribution out of normality at the 0.10 significance level $(W=0.314$, $p$-value $<0.0001$; Figure 5 ).

After defining a regression equation that was adequate for estimating the age of the trees, we evaluated the yield of copaiba oleoresin and proportion of productive trees according to DBH class, age class, and MAI of DBH class (Figure 6). Few individuals with either a small or a large $\mathrm{DBH}$ were productive, but there was a high proportion of productive individuals in the intermediate class of DBH $(0.54 \mathrm{~m}$ to $0.66 \mathrm{~m})$. This proportion was reduced in the largest diameter class $(0.66 \mathrm{~m}$ to $0.78 \mathrm{~m}$ ). The Pearson coefficient of correlation between

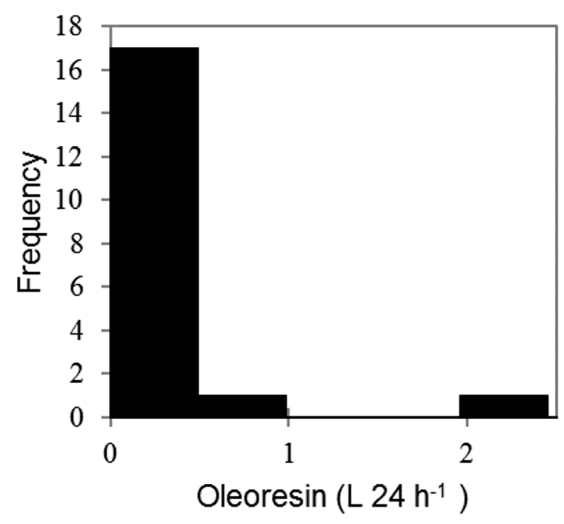

FIGURE 5 Histogram of the yield of Copaifera oleoresin in the Cerrado-Amazonia ecotone in the central north region of Mato Grosso State, Brazil. 
age and $\mathrm{MAl}$ of $\mathrm{DBH}(r=-0.77)$ indicated a significant inverse relationship between these characteristics (i.e., as the age increases, the MAl of DBH decreases, and the proportion of productive trees increases).
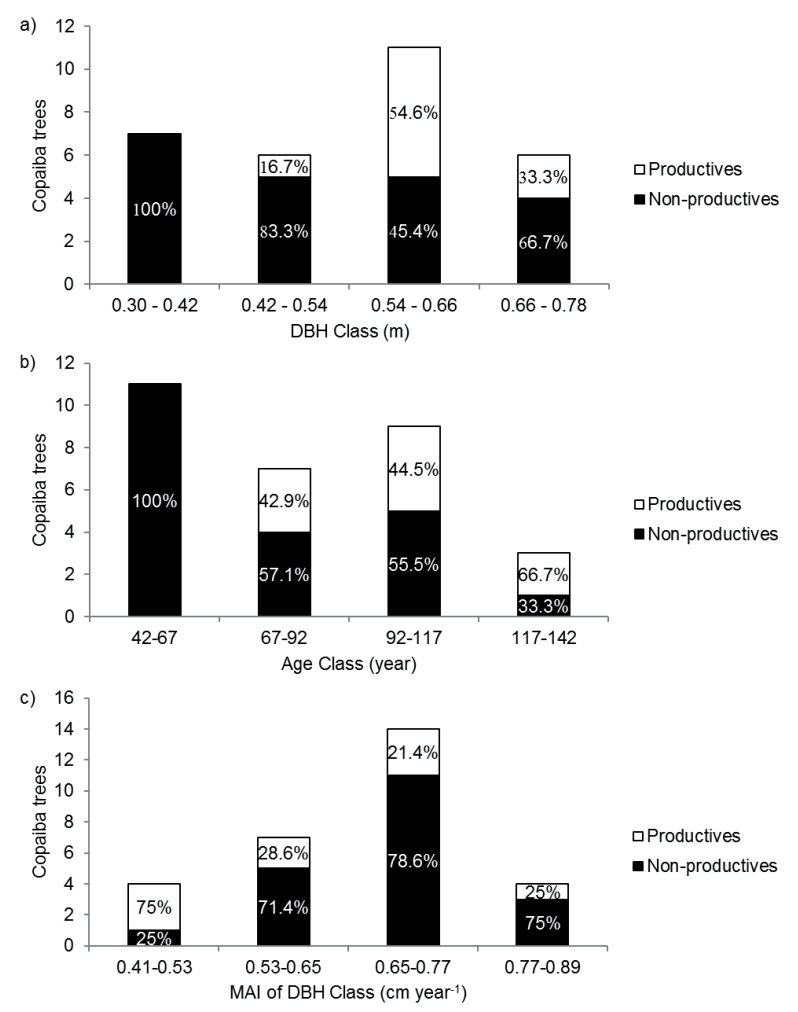

FIGURE 6 Distribution of productive and non-productive Copaifera trees according to the (a) diameter at breast height $(\mathrm{DBH})$ class; (b) age class; and (c) mean annual increment (MAl) of DBH class in the CerradoAmazonia ecotone in the central north region of Mato Grosso State, Brazil.

\section{DISCUSSION}

The heterogeneity of natural tropical forests confers a high diametric amplitude to the trees, which could be why $\mathrm{R}^{2}$ adjust. showed a weaker relationship between age and $\mathrm{DBH}$ than that observed in studies of forest plantations, in which the diametric amplitude tended to be more homogeneous (Finger et al., 1996; Canto and Schneider, 2004; Schneider et al., 2006; Sanquetta et al., 2010). There are few models that predict tree growth using tree size variables in tropical rainforests (Da Cunha et al., 20l6). Therefore, even though $\mathrm{R}^{2}$ adjust. Was lower than that observed in the adjusted equations for planted forests, the age equation for the copaiba trees in the study was used to estimate the age of the trees for which the variable was not determined.
Results on the relationship between growth and age in copaíba trees provide valuable data to improve the science and management of Copaifera (Free et al., 2017). Da Cunha et al. (2016) verified that copaiba trees may have lower growth rates than other Amazonian species. In the Cerrado-Amazonia ecotone, the dry season may limit tree growth, causing these rates to be even lower (Nepstad et al., 2004).

The distribution of productive trees with regard to $\mathrm{DBH}$ is similar to the results obtained in other studies, which verified that individuals with smaller diameters were less productive or completely non-productive. The intermediate classes showed higher values for oleoresin yield, whereas individuals in the higher diameter class were less productive or non-productive, as in the lower diameter class (Alencar, 1982; Plowden, 2003; Rigamonte-Azevedo et al., 2006; Barbosa et al., 2009; Souza and Higuchi, 20I4).

A similar relationship was also verified by Baima et al. (1999), who observed that copaiba trees with $\mathrm{DBH}$ less than $0.60 \mathrm{~m}$ did not produce oleoresin, while those with $\mathrm{DBH}$ between 0.60 and 0.93 m produced oleoresin in proportional to the increase in diameter. These authors did not mention whether there was a decrease in yield in the trees with larger diameters.

Plowden (2003) showed that very young, very old, or hollow Copaifera trees do not produce or produce little oleoresin in their trunks; thus, age and a minimum $\mathrm{DBH}$ value are preconditions for selecting trees for extraction. Plowden (2003) also indicated that circumstances in some trees may induce the production of oleoresin above the average value in living tissues during middle age, and a different set of circumstances may lead to the creation of cavities filled with oleoresin in the heartwood at an advanced age.

In the present study, while the number of productive individuals increased in accordance with the age class, the opposite trend was observed with respect to $\mathrm{MAI}$ of $\mathrm{DBH}$. This finding can be related to tree growth under unfavorable conditions (e.g., water deficit, toxic elements in the soil, fungus, and pest attack) or to the senescence phase of the individuals mentioned by Plowden (2003). However, further studies should test this hypothesis and evaluate other related factors, considering that the non-productive individuals were also observed that had a superior MAI.

Wide variation in the yield of copaiba oleoresin was also observed in other studies, like that sampled trees in the Brazilian Amazon (Table I). All of these studies reported that some trees were non-productive, 
and the average yield of copaiba oleoresin was within the range reported in this study (Alencar, 1982; Baima et al., 1999; Plowden, 2003; Oliveira et al., 2006; RigamonteAzevedo et al., 2006; Barbosa et al., 2009; Newton et al., 20I I; Martins et al., 20I3; Souza and Higuchi, 20I4).
The Amazon region is rich in natural resources and has a great diversity of economically important species. Studying them can improve the management techniques and technologies for the appropriate use of their products and by-products (Baima et al., 1999). The high

TABLE I Summary of the yield of Copaifera oleoresin in the Amazon according to the literature. $p=$ productive trees only; cs= clay soil; ss=sandy soil; $u$ l= upland; $\|$ =lowland; $y=$ yellow copaiba; $w=$ white copaiba; $b=$ black copaiba; $r=$ red copaiba.

\begin{tabular}{|c|c|c|c|c|c|}
\hline Author & Site & Species & $\begin{array}{c}\text { Min.-Max. } \\
\left(\text { L-tree }{ }^{-1}\right)\end{array}$ & $\begin{array}{c}\text { Average yield } \\
\left(L \cdot \text { tree }^{-1}\right)\end{array}$ & $\begin{array}{l}\text { Production } \\
(\%)\end{array}$ \\
\hline \multirow{14}{*}{ Alencar (1982) } & \multirow{14}{*}{ Central Amazonia } & \multirow{14}{*}{ C. multijuga } & \multicolumn{3}{|c|}{ Ist extraction (March/June 1977) } \\
\hline & & & $0-2.85 \mathrm{cs}$ & $0.23 \mathrm{cs}$ & $38.6 \mathrm{cs}$ \\
\hline & & & $0-1.95 \mathrm{ss}$ & $0.16 \mathrm{ss}$ & 24.0ss \\
\hline & & & \multicolumn{3}{|c|}{ 2nd extraction (December/January 1978) } \\
\hline & & & $0-3.5 \mathrm{cs}$ & $0.13 \mathrm{cs}$ & $21.5 \mathrm{cs}$ \\
\hline & & & $0-1.3 \mathrm{ss}$ & 0.10 ss & 28.0 ss \\
\hline & & & $0-1.37 \mathrm{cs}$ & $0.04 \mathrm{cs}$ & $10.5 \mathrm{cs}$ \\
\hline & & & $0-0.5 \mathrm{ss}$ & $0.04 \mathrm{ss}$ & $28.0 \mathrm{ss}$ \\
\hline & & & \multicolumn{3}{|c|}{ 4th extraction (September/November 1979) } \\
\hline & & & $0-1.57 \mathrm{cs}$ & $0.05 \mathrm{cs}$ & $10.5 \mathrm{cs}$ \\
\hline & & & $0-0.23$ ss & $0.02 \mathrm{ss}$ & $12.0 \mathrm{ss}$ \\
\hline & & & \multicolumn{3}{|c|}{ 5th extraction (December 1980) } \\
\hline & & & $0-0.45 \mathrm{cs}$ & $0.03 \mathrm{cs}$ & $12.3 \mathrm{cs}$ \\
\hline & & & $0-0.75$ ss & $0.03 \mathrm{ss}$ & $12.0 \mathrm{ss}$ \\
\hline \multirow{6}{*}{$\begin{array}{l}\text { Ferreira and Braz } \\
\qquad(200 \mathrm{I})\end{array}$} & \multirow{6}{*}{ Western Amazonia } & \multirow{6}{*}{ Copaifera sp. } & \multicolumn{3}{|c|}{ Extraction (October/November 1997) } \\
\hline & & & - & 0.57 & 40.9 \\
\hline & & & & $1.36 \mathrm{ul} 0.12 \mathrm{ll}$ & $43.7 \mathrm{ul} \quad 39.3 \|$ \\
\hline & & & & raction (July/Au & \\
\hline & & & - & 1.70 & 72.0 \\
\hline & & & & $2.10 \mathrm{ul} 0.32 \|$ & 85.7 ul 25.0Il \\
\hline \multirow{6}{*}{ Plowden (2003) } & \multirow{6}{*}{ Eastern Amazonia } & \multirow{6}{*}{ Copaifera spp. } & \multicolumn{3}{|c|}{ Ist extraction (July/August I996) } \\
\hline & & & - & $0.071 \pm 0.039$ & 31.0 \\
\hline & & & \multicolumn{3}{|c|}{ 2nd extraction (November 1997) } \\
\hline & & & - & $0.007 \pm 0.005$ & 36.4 \\
\hline & & & \multicolumn{3}{|c|}{ Extraction (May 1998) } \\
\hline & & & - & $0.007 \pm 0.005$ & 38.1 \\
\hline \multirow{7}{*}{$\begin{array}{l}\text { Rigamonte- } \\
\text { Azevedo et al. } \\
\text { (2006) }\end{array}$} & & & & on (January/Febr & 02) \\
\hline & & Copaifera spp. & $0-18$ & 0.94 & 32.2 \\
\hline & & C. reticulatay & $0-11$ & 1.04 & 30.0 \\
\hline & Southwest Amazonia & C. reticulataw & $0-4.5$ & 0.48 & 30.0 \\
\hline & & C. cf paupera & $0-4.6$ & 1.33 & 81.5 \\
\hline & & C. reticulatab & $0-18$ & 1.14 & 29.6 \\
\hline & & C. reticulatar & $0-5.5$ & 0.38 & 24.3 \\
\hline & & & & xtraction (rainy & \\
\hline Barbosa et al. & Central Amazonia & C multiiuбa & $0-2.17$ & 0.33 & 43.7 \\
\hline (2009) & Central Amazonia & C. multijuga & & Extraction (dry & \\
\hline & & & $0-0.53$ & 0.03 & 5.9 \\
\hline & & & Ext & uary/December & ril 20I0) \\
\hline & & C. multijuga & $0-4.25$ & $0.5 \mathrm{Ip}$ & 55.0 \\
\hline Newton et al. & Western Amazonia & C. piressi & $0-0.03$ & $0.02 p$ & 19.0 \\
\hline$(20 I I)$ & & C. guyanensis & $0-0.03$ & $0.02 p$ & 9.1 \\
\hline & & C. guyanensis & $0-1.04$ & $0.14 p$ & 32.8 \\
\hline & & C. paupera & $0-0.27$ & $0.11 p$ & 16.7 \\
\hline & & & & October $2006 \mathrm{t}$ & 2008) \\
\hline & & Copaifera spp. & - & - & 41.8 \\
\hline & & C. paupera & $0-2.93$ & $0.52 p$ & 46.7 \\
\hline$(2013)$ & Amazonia & C. reticulara & $0-2.76$ & $0.45 p$ & 62.1 \\
\hline & & C. pubiflora & $0-5.5 I$ & $1.70 p$ & 31.4 \\
\hline & & C. multijuga & $0-1.40$ & $0.66 p$ & 18.8 \\
\hline & & & & m unexplored & y 2008) \\
\hline Souza and Higushi & & & $0-0.95$ & 0.10 & 41.0 \\
\hline$(20 \mid 4)$ & Southwest Amazonia & C. multijuga & & m re-explored & ly 2008) \\
\hline & & & $0-3.60$ & 0.16 & 39.0 \\
\hline Present study & Cerrado-Amazonia & & & ction (July/Sept & \\
\hline Present study & ecotone & Copaifera spp. & $0-2.35$ & 0.12 & 30.0 \\
\hline
\end{tabular}


variability in the productive trees and yield demonstrates the importance of identifying the production factors for copaiba oleoresin. Estimates and production forecasts are essential to define limits to the harvest pressure in order to harvest this non-timber product sustainably (Ticktin, 2004). This is the first study of yield of copaiba oleoresin in the Cerrado-Amazonia ecotone, and for this reason we encourage other studies in the region so that the data they collect may be compared with our findings.

Exploitation of non-timber forests to extract non-timber products or sub-products, as well as for agriculture and livestock rearing, is an alternative that may aid conservation of tropical forests and reduce land use change in tropical forests (Ferreira and Braz, 200I; Machado, 2008). Because of its market potential, especially in the pharmaceutical industry, copaiba oleoresin is highly in demand, both in Brazil and abroad; however, the lack of a good production base makes the commercial exploitation of copaiba difficult (Leite et al., 200I).

\section{CONCLUSIONS}

It was possible to estimate the age of copaiba trees in the primary forest on the basis of DBH data by using regression analysis. However, the selection of the matrix trees for oleoresin extraction could not be based only on $\mathrm{DBH}$, as each individual tree experiences different conditions that affect its growth, so the correlation between age and $\mathrm{DBH}$ is not as strong as that in homogeneous (artificial) forests. The results suggest that other factors could be triggering and controling the oleoresin production and not only the age. In the primary forest in the Cerrado-Amazonia ecotone, only trees with a DBH of at least $0.42 \mathrm{~m}$ and an age of at least 67 years produce oleoresin. However, the use of $\mathrm{DBH}$ to identify productive trees can lead to errors, because the proportion of productive trees with high $\mathrm{DBH}$ tends to be lower than that of productive trees in the intermediate DBH class. Finally, high variation in the yield of oleoresin was observed in all classes of the variables studied (DBH, age, and $M A I$ of $D B H$ ), including non-productive individuals, with the exception of trees in the lower classes of $\mathrm{DBH}$ and age, which were non-productive.

\section{REFERENCES}

ALENCAR, J. C. Estudos silviculturais de uma população natural de Copaifera multijuga Hayne - Leguminosae, na Amazônia Central. 2 - Produção de óleo-resina. Acta Amazônica, v. 12, p. 75-89, 1982.

BAIMA, A. M. V.; SANTOS, L. S.; NUNES, D. S.; CARVALHO, J. O. P. Produção de óleo de copaíba na região do Tapajós. EMBRAPA-CPATU Belém, Pará (EMBRAPACPATU, Comunicado Técnico, 103). 1999. 3p.
BARBOSA, K. S.; SCUDELLER, V. V.; ROSA, A. L. Potencial de produção de óleo resina de Copaifera multijuga Hayne nos dois períodos climáticos amazônico na Reserva de Desenvolvimento Sustentável do Tupé, Manaus-AM. In: SANTOS-SILVA, E. N.; SCUDELLER, V. V. (Org.). Biotupé: meio físico, diversidade biológica e sociocultural do baixo do Rio Negro, Amazônia Central. v. 2., cap.l 2. UEA Edições, Manaus, Amazonas. 2009. I0p.

CANTO, J. L.; SCHNEIDER, P. R. Crescimento da Grevillea robusta A. Cunn. na depressão central do Rio Grande do Sul, Brasil. Ciência Florestal, v. 14, p. 29-35, 2004.

DA CUNHA, T. A.; FINGER, C. A. G.; HASENAUER, H. Tree basal area increment models for Cedrela, Amburana, Copaifera and Swietenia growing in the Amazon rain forests. Forest Ecology and Management, v. 365, p. I74-183, 2016.

FERREIRA, L. A.; BRAZ, E. M. Avaliação do potencial de extração e comercialização do óleo-resina de copaíba (Copaifera sp.). In: DALY, D. C.; SILVEIRA, M.; FERREIRA, E. J. L. Florística e Botânica Econômica do Acre. The New York Botanical Garden/Universidade Federal do Acre, Rio Branco, Acre. p. I-17, 200I. Available at: http://www.nybg.org/bsci/acre/ wwwl/evaluation.html. Accessed in: 06 may 2017.

FINGER, C. A. G.; ELEOTÉRIO, J. R.; BERGER, R.; SCHNEIDER, P. R. Crescimento diamétrico do pau-ferro (Astronium balansae) em reflorestamento no município de São Sepé, RS. Ciência Florestal, v. 6, p. I01-108, 1996.

FREE, C. M.; GROGAN, J.; SCHULZE, M. D.; LANDIS, R. M.; BRIENEN, R. J. W. Current Brazilian forest management guidelines are unsustainable for Swietenia, Cedrela, Amburana, and Copaifea: A response to da Cunha and colleagues. Forest Ecology and Management, v. 386, p. 8I-83, 2017.

HAIR, J. F; BLACK, W. C.; BABIN, B. J.; ANDERSON, R. E.; TATHAM, R. L. Análise multivariada de dados. 6ta ed., Editora Bookman, Porto Alegre, Rio Grande do Sul. 2009. 688p.

IBGE. Mapa de geologia do estado de Mato Grosso. Ist ed., Instituto Brasileiro de Geografia e Estatística. 2009a. Available at: ftp://geoftp.ibge.gov.br/informacoes_ ambientais/geologia/levantamento_geologico/mapas/ unidades_da_federacao/mt_geologia.pdf. Accessed in: 06 february $\overline{2} 01 \overline{7}$.

IBGE. Mapa de geomorfologia do estado de Mato Grosso. Ist ed. Instituto Brasileiro de Geografia e Estatística. 2009b. Available at: ftp://geoftp.ibge.gov.br/informacoes_ ambientais/geomorfologia/mapas/unidades_da_federacao/ $\mathrm{mt}$ _geomorfologia.pdf. Accessed in: 06 february 2017.

IBGE. Mapa de pedologia do estado de Mato Grosso. Ist ed. Instituto Brasileiro de Geografia e Estatística. 2009c. Available at: ftp://geoftp.ibge.gov.br/informacoes_ ambientais/pedologia/mapas/unidades_da_federacao/mt_ pedologia.pdf. Accessed in: 06 february $20 \bar{I} 7$. 
IBGE. Manual técnico da vegetação brasileira. Manuais técnicos em geociências. 2nd ed., I, Instituto Brasileiro de Geografia e Estatística, Rio de Janeiro, Rio de Janeiro. 2012.

INMET. Normais climatológicas do Brasil 196I-1990: precipitação acumulada mensal e anual (mm). Instituto Nacional de Meteorologia. 2009. Available at: http://www.inmet.gov.br/portal/index.php?r=clima/ normaisClimatologicas. Accessed in: 06 february 2017.

LEITE, A.; ALECHANDRE, A.; RIGAMONTE-AZEVEDO, C. L.; CAMPOS, C. A.; OLIVEIRA, A. Recomendações para o manejo sustentável do óleo de copaíba. UFAC/SEFE, Rio Branco, Acre (Série Manejo Sustentável de Florestas Tropicais). 200 I. 20 p.

LÓPEZ, L.; VILLALBA, R.; BRAVO, F. Cumulative diameter growth and biological rotation age for seven tree species in the Cerrado biogeographical province of Bolivia. Forest Ecology and Management, v. 292, 20I3.

MACHADO, F. S. Manejo de produtos florestais não madeireiros: um manual com sugestões para o manejo participativo em comunidades da Amazônia. PESACRE e CIFOR, Rio Branco, Acre. 2008.

MAINIERI C.; CHIMELO, J. P. Fichas de características das madeiras brasileiras. 2da ed. Instituto de Pesquisas Tecnológicas, São Paulo, São Paulo. 1989, 409p.

MARTINS-DA-SILVA, R. C. V. Taxonomia das espécies do gênero Copaifera L. (Leguminosae-Caesalpinoideae) ocorrentes na Amazônia brasileira. 2006. 258 p. Tese de Doutorado. Universidade Federal do Rio de Janeiro, Rio de Janeiro.

MARTINS-DA-SILVA, R. C. V.; PEREIRA, J. F.; LIMA, H. C. O gênero Copaifera (Leguminosae-Caesalpinoideae) na Amazônia brasileira. Rodriguésia, v. 59, n. 3, p. 455-476, 2008.

MARTINS, K.; HERRERO-JÁUREGUI, C.; COSTA, P.; TONINI, H.; BENTES-GAMA, M. M.; VIEIRA, A. H.; WADT, L. H. $O$. Interspecific differences in the oleoresin production of Copaifera L. (Fabaceae) in the Amazon rainforest. Annals of Forest Science, v. 70, p. 319-318, 2013.

MEDEIROS, R. S.; VIEIRA, G. Sustainability of extraction and production of Copaiba (Copaifera multijuga Hayne) oleoresin in Manaus-AM, Brazil. Forest Ecology and Management, v. 256, p. 282-288, 2008.

NEPSTAD, D.; LEFEBVRE, P.; DA SILVA, U. L.; TOMASELLA, J.; SCHLESINGER, P.; SOLÓRZANO, L.; MOUTINHO, P.; RAY, D.; BENITO, J. G. Amazon drought and its implications for forest flammability and tree growth: a basin-wide analysis. Global Change Biology, v. I0, p. 704-7I 7, 2004.

NEWTON, P.; WATKINSON, A. R.; PERES, C. A. Determinants of yield in a non-timber forest product: Copaifera oleoresin in Amazonian extractive reserves. Forest Ecology and Management, v. 26I, p. 255-264, 201 I.
OLIVEIRA, E. C. P.; LAMEIRA, O. A.; ZOGHBI, M. G. B. Identificação da época de coleta do óleo-resina de copaíba (Copaifera sp.) no município de Moju, PA. Revista Brasileira de Plantas Medicinais, v. 8, p. I4-23, 2006.

PEREIRA, M. G.; CARVALHO, D. C.; LATORRACA, J. V. F; COSTA, J. H.; SILVA, L. D. S. A. B.; CARMO, J. F. Dendrochronology and growth of Copaifera langsdorffii wood in the vegetatitve dynamics of the Pirapitinga Ecological Station, State of Minas Gerais, Brazil. Revista Floresta, n. 48, n. I, p. 49-58, 2018.

PIERI, F. A.; MUSSI, M. C.; MOREIRA, M. A. S. Óleo de copaíba (Copaifera sp.): histórico, extração, aplicações industriais e propriedades medicinais. Revista Brasileira de Plantas Medicinais, v. I I, p. 465-472, 2009.

PLOWDEN, C. Production ecology of copaíba (Copaifera sp.) oleoresin in the Eastern Brazilian Amazon. Economic Botany, v. 57, p. 49I-50I, 2003.

RIGAMONTE-AZEVEDO, O. C.; WADT, P. G. S.; WADT, L. H. O.; VEIGA JUNIOR, V. F.; PINTO, A. C.; REGIANI, A. M. Variabilidade química e física do óleo-resina de Copaifera sp. no sudoeste da Amazônia brasileira. Revista Brasileira de Ol. Fibros., v. 8, p. 85I-86I, 2004.

RIGAMONTE-AZEVEDO, O. C.; WADT, P. G. S.; WADT, L. H. O. Potencial de produção de óleo-resina de copaíba (Copaifera sp.) de populações naturais do sudoeste da Amazônia. Revista Árvore, v. 30, p. 583-591, 2006.

SANQUETTA, C. R.; WEBER, S. H.; FORMAGINI, F; BARBEIRO, L. S.; VIEIRA, G. Equações individuais e determinação de classes de crescimento para Nectandra grandiflora Ness a partir de dados de análise de tronco. Scientia Agraria, v. I I, p. I-8, 2010.

SCHNEIDER, P. S. P.; SCHEEREN, L. W.; SCHNEIDER, P. R.; FINGER, C. A. G. Crescimento da Cordia trichotoma (Vell.) Arrab. Ex Steud. na depressão central do Estado do Rio Grande do Sul. Floresta e Ambiente, v. I3, p. 26-33, 2006.

SOUZA, F. D. R.; HIGUCHI, N. O manejo da copaíba pelas etnias Arara e Gavião na Terra Indígena Igarapé Lourdes, Rondônia, Norte do Brasil. Revista Ceres, v. 6I, p. 28-34, 2014.

TICKTIN, T. The ecological implications of harvesting nontimber products. Journal of Applied Ecology, v. 4I, p. I I-2I, 2004.

VEIGA JUNIOR, V. F; PINTO, A. C. O gênero Copaifera L. Revista Química Nova, v. 25, p. 273-286, 2002.

VLAM, M.; BAKER, P. J.; BUNYAVEJCHEWIN, S.; MOHREN, G. M. J.; ZUIDEMA, P. A. Understanding recruitment failure in tropical tree species: insights from a tree-ring study. Forest Ecology and Management, v. 312, p. 108-116, 2014. 